EVALUASI, 4 (1), Maret 2020, ISSN 2580-3387 (print) |

ISSN 2615-2886 (online)

Homepage : http://e-journal.staima-alhikam.ac.id/index.php/evaluasi

DOI : : http://doi.org/10.32478/evaluasi.v4i1.359

Article type : Review Article

\title{
KH Hasyim Asy'ari and the Teacher Code of Ethics: Thought Study KH. Hasyim Asy'ari on Ethics Education and Its Relevance to Modern Education in Indonesia
}

Siswoyo Aris Munandar

Sekolah Tinggi Agama Islam Sunan Pandanaran Yogyakarta

Rinda Khoirunnisfa

State Islamic Institute Ponorogo

\begin{abstract}
This study started with the problem of the moral crisis that hit many rites Karima learners in Indonesia increasingly pay attention to. The moral values and morals in the modern era increasingly eroded, the student became pregnant outside of wedlock, resulting in a brawl between students, rampant drug use, and abuse of students to teachers even lead to death. KH. M. Hasyim Asy'ari about education schools as well as revealing the sides of modernity that are relevant to the present condition of education. The core of this study lies in the greatness of $\mathrm{KH}$. M. Hasyim Asy'ari in changing the pesantren education system starting from the intake of moralistic characters. A breakthrough is impressive and remains relevant to the existence of schools today. Concerning some of the literature about him, This research uses a literature review with qualitative research. Data were taken from newspapers, articles, journals, books and other documents. The data were analyzed using content analysis philological, where analyzes of the educational thought $\mathrm{KH}$. M. Hasyim Asy'ari associated with its development in the present. The research results lead to the conclusion, 1) To describe the relevance of ethics in Islamic education teachers according to the code of conduct $\mathrm{KH}$. M. Hasyim Asy'ari teachers in Indonesia. 2). To describe the thought $\mathrm{KH}$. M. Hasyim Asy'ari Islamic education and ethics of teachers to students. (3). source destination educational thought by $\mathrm{KH}$. M. Hasyim
\end{abstract}

114 Email: siswoyoaris31@gmail.com, Rindakhoirunisfa@gmail.com EVALUASI: Jurnal Manajemen Pendidikan Islam is licensed under The CC BY License (https://creativecommons.org/licenses/by-sa/4.0/) 
EVALUASI, 4 (1), Maret 2020, ISSN 2580-3387 (print) I

ISSN 2615-2886 (online)

Homepage : http://e-journal.staima-alhikam.ac.id/index.php/evaluasi

DOI : : http://doi.org/10.32478/evaluasi.v4i1.359

Article type : Review Article

Asy'ari is to humanize the position as creatures who gave birth to awareness to their rights and obligations to God the creator of man,

Keywords: KH. Hasyim Ashari, Teacher Ethics, Modern Education.

\section{Abstrak}

Penelitian ini berawal dari permasalahan krisis akhlak karimah yang menimpa manyoritas peserta didik di Indonesia semakin memperhantikan. Nilai-nilai ahlak dan moral di era modern semakin terkikis, siswa hamil diluar nikah, sehingga mengakibatkan tawuran antarpelajar, penggunaan narkoba semakin merajalela, serta penganiayaan siswa terhadap guru yang bahkan sampai berujung kepada kematian. KH. Hasyim Asy'ari tentang pendidikan pesantren serta mengungkap sisi-sisi modernitas yang relevan dengan kondisi pendidikan masa kini. Inti Dari penelitian ini terletak pada kehebatan $\mathrm{KH}$. Hasyim Asy'ari dalam merubah sistem pendidikan pesantren mulai dari asupan karakter yang bersifat moralistic. Suatu terobosan besar yang mengesankan dan tetap relevan dengan eksistensi pendidikan masa kini. Dengan merujuk pada beberapa literatur yang menyangkut dengan beliau, penelitian ini menggunakan kajian pustaka dengan jenis penelitian kualitatif. Data diambil dari Koran, artikel-artikel, jurnal, buku dan dokumen lain. Data tersebut dianalisis menggunakan analisis isi yang filologis, di mana menganalisis terhadap pemikiran pendidikan $\mathrm{KH}$. Hasyim Asy'ari dikaitkan dengan perkembangannya di masa kini. Dari hasil penelitian menghasilkan kesimpulan, 1) Untuk mendeskripsikan relevansi etika guru dalam pendidikan Islam menurut KH.Hasyim Asy'ari dengan kode etik guru di indonesia. 2). Untuk mendeskripsikan pemikiran $\mathrm{KH}$. Hasyim Asy'ari pendidikan Islam dan Etika guru terhadap murid. (3). sumber tujuan pemikiran pendidikan menurut $\mathrm{KH}$. Hasyim Asy'ari adalah memanusiakan pada posisinya sebagai ciptaan yang melahirkan kesadaran untuk melakukan hak dan kewajibannya kepada Tuhan pencipta manusia, inilah yang menjadi embrio lahirnya pendidikan karakter.

Kata Kunci: Hasyim Asy'ari, Etika Guru, Pendidikan Modern. 


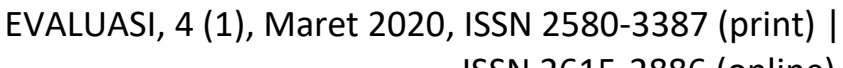

ISSN 2615-2886 (online)

Homepage : http://e-journal.staima-alhikam.ac.id/index.php/evaluasi

DOI : : http://doi.org/10.32478/evaluasi.v4i1.359

Article type : Review Article

\section{A. INTRODUCTION}

Education ${ }^{1}$ is one of the efforts to design the future of mankind in the concept and its implementation must take into account various factors that influence our value system. According to AL Tibawi, factors and education system that is applied in Arab Muslim countries, which incidentally are mostly former colonies of the Europeans (Britain, France, and others), has led to fragmentation and transformation in the education system. In such a position is certainly understandable process will occur tug of war between the west inherited the colonial hegemony and remedial efforts and the

1 in this context education has two main functions, namely the function of a conservative and progressive function. Conservative function as passes and maintain the identity and ideals of a society. While the progressive function is to attempt to provide educational activities debriefing and development of knowledge, values, and skills so that the next generation has the competitive ability and preparedness to face life in the future. See Abuddin Nata, Kapita Selekta Pendidikan Islam, (Bandung: Penerbit Angkasa, 2003). 39-40; Abdurrahman Umdirah, Metode al-Qur'an dalam Pendidikan, alih bahasa; Abdul Hadi Basulthanah, (Surabaya: Mutia Ilmu, tt), 15. Meanwhile, according to Amin Rais-in essence-Education is a process consisting of at least three activities of life, namely; ta'lim, tarbiyah and ta' dib. Ta'lim is a sense of enlightenment process protégé. Thus becoming enlightened, enlightened mind (so smart), and can understand the various sciences. Tarbiyah means educating, instilling an awareness of humane and responsible both individually and collectively; and ta'dib was made man truly civilized manners high. See M. Amin Rais, Social Tauhid: Formula pounding the gap, (Bandung: Mizan, 1998), 290. Meanwhile, Azyumardi Azra revealed education, among others: and responsible both individually and collectively; and ta' dib was made man truly civilized manners high. See, Amin Rais, Tauhid Sosial: Formula Menggempur Kesenjangan, (Bandung: Mizan, 1998), 290. Meanwhile, Azyumardi Azra revealed on education, among others:

"Education is more than teaching because, in reality, education is a process in which a nation or state to foster and develop self-awareness among individuals. With the consciousness of a nation or country or culture can bequeath wealth to the next generation of thought, so that was the inspiration for them in every aspect of life. ". Abuddin Nata, Kapita Selekta, hal. 40; Muslih Usa, Pendidikan Islam di Indonesia Antara Cita dan Fakta, (Yogyakarta: Tiara Wacana, 1991), 8 in Rohinah, "Sistem Nilai dan Pendidikan (Studi atas Pemikiran Pendidikan KH. M. Hasyim Asy'ari)", Konsentrasi Pendidikan Agama Islam Sekolah Pascasarjana UIN Syarif Hidayatullah Jakarta, 2008, 1

116 
EVALUASI, 4 (1), Maret 2020, ISSN 2580-3387 (print) |

ISSN 2615-2886 (online)

Homepage : http://e-journal.staima-alhikam.ac.id/index.php/evaluasi

DOI $\quad$ : http://doi.org/10.32478/evaluasi.v4i1.359

Article type : Review Article

search for Islamic education system entities. ${ }^{2}$ Education should be able to deliver humanity to benefit, to the happiness of the world and the hereafter. Education should be able to develop and preserve the good values and norms of Islam to future generations of the people, and the nation's future. Muslims should be developed in a variety of science that we do not fool by nation or people that are not in line with ours. Muslims should be run by the values and norms of Islam. ${ }^{3}$

4.0 Entering the industrial revolution characterized by the pattern of all-digital communication (Internet of Things) with a sense of entrepreneurs, demanding Islamic education (schools) to reorient, review it or metamorphosis. Because we realize it or not, the readiness and the role of the successor generation of civilization shall occupy a strategic position to reach the goal. If not, it is not impossible to slowly will fall far and hard to compete with other educational products that have been dashed following the development of the era. Pesantren, growth, and development are always unique and dynamic. Various models and educational framework is applied, do not make boarding extinct or declining. The existence of pesantren always exciting to be highlighted, from figure Kiai as a single authority, students often do innovation and achievement, ${ }^{4}$

Education conducted in every educational institution aims to make the best humans to a certain perspective. ${ }^{5}$ That is the purpose of education depends on a person's thinking pattern of life; if thinking tends to philosophy,

2 A.L. Tibawi, Islamic Education: Its Traditions and Modernization into the Arab National Systems (London: Luzac, 1972), 202; Philip K. Hitty, History of the Arabs, (London: Macmillan Press, 1974), 756 dalam Rohinah, Sistem Nilai dan Pendidikan (Studi atas Pemikiran Pendidikan KH. M. Hasyim Asy'ari), Konsentrasi Pendidikan Agama Islam Sekolah Pascasarjana UIN Syarif Hidayatullah Jakarta, 2008, 2.

3 Azyumardi Azra, Pembaruan Pendidikan Islam: Sebuah Pengantar" dalam Marwan Saridjo, Bunga Rampai Pendidikan Islam, (Jakarta: Departemen Agama RI, 1997/1998), 2. And Mahrus As'ad. Pembaruan Pendidikan Islam KH. Hasyim Asy'ari. Jurnal TSAQOFAH, Vol. 8 No. 1 April 2012, . 106

${ }^{4}$ Muh. Saerozi, Pembaruan Pendidikan Islam: Studi Historis Indonesia dan Malaysia1900-1942, (Yogyakarta: Tiara Wacana, 2013), 85-86.

5 Rini Yuliyanti, "Hubungan Guru Dan Murid Menurut KH. Hasyim Asy'ari Dan Implementasinya Dalam Tradisi Pembelajaran Di Pondok Pesantren Nurul Hikmah" Undergraduate, UIN Raden Intan Lampung, 2017, http://repository.radenintan.ac.id/1371/, 198. 
EVALUASI, 4 (1), Maret 2020, ISSN 2580-3387 (print) |

ISSN 2615-2886 (online)

Homepage : http://e-journal.staima-alhikam.ac.id/index.php/evaluasi

DOI : : http://doi.org/10.32478/evaluasi.v4i1.359

Article type : Review Article

the purpose of education will be patterned philosophy, whereas if the thoughts tend to religion, then the goal will be based on religious education. ${ }^{6}$ The formulation of the purpose of education depends on the concept of education to be achieved. Islamic education aims to optimize all the potential inherent in human beings for the sake of getting closer to Allah. to achieve complete happiness in this world and the hereafter. ${ }^{7}$ It also will establish a good relationship between one individual to individual, and the relationship between man and the universe.

In other words, Islamic education aims to optimize all the potential physical and spiritual to print a Muslim who obey God and building a good relationship with man and nature, so that he could obtain the happiness of the world and at the However, the current reality is inversely proportional to the vision and the mission to be achieved in Islamic education. Moral degradation has many befall learners in Indonesia at every level of education, resulting in a wide range of issues of concern, such as drug use rampant among young people, brawl between students, pregnant out of wedlock, fading respect of students to teachers, and even persecution students to the teacher that led to the death of his teacher and keranah law. These problems are supposed to be embedded in the self-learners.

The moral crisis that often befalls such learners makes educational goals difficult to achieve. Therefore, the achievement of educational goals depends on the realization of the value that is formed in the human person desired. ${ }^{8}$ Ethics and morality crisis that hit the Indonesian education in the last 20 years to reap the anxiety itself. Educational development marked by the opening of the valves open and free technology, offering two events simultaneously. One side, a positive impact on improving the quality and knowledge, but on the other hand carries the barriers that are not able to be filtered and its implications on the character and attitude (attitude)

\footnotetext{
${ }^{6}$ Muh Shofi Al Mubarok and Sudarno Shobron, "Dakwah Dan Jihad Dalam Islam: Studi Atas Pemikiran KHM Hasyim Asy'ari," Profetika: Jurnal Studi Islam, Vol. 16, no. 2 (2017), 137.

${ }^{7}$ Muh. Saerozi, Pembaruan Pendidikan Islam. 90.

${ }^{8}$ Ibid., 
EVALUASI, 4 (1), Maret 2020, ISSN 2580-3387 (print) |

ISSN 2615-2886 (online)

Homepage : http://e-journal.staima-alhikam.ac.id/index.php/evaluasi

DOI $\quad$ : http://doi.org/10.32478/evaluasi.v4i1.359

Article type : Review Article

generation of people. Abdurrahman, claiming that advances education co accompanied by a weak character that the impact is much more worrying. ${ }^{9}$

Counteracting these conditions, the only institution that is foster moral and ethics (code) is a boarding school. In addition to teaching general knowledge and education-oriented modern pesantren has a characteristic that strengthens the character and the character of the students. Athiyah alAbrasyi said that the essence of education is the cultivation of character that comes from aqidah and tawhid. ${ }^{10}$ The existence of the character values combined with modern science that spawned the comprehensive totality of knowledge.

Pesantren as sub-national indigenous education system seen by many as having advantages and characteristics, especially in character education. Assumptions thus departing from boarding institutions using the hostel system and easy to instill moral values. ${ }^{11}$ With this assumption, the history is not only a successful character education inscribed by schools, even according $\mathrm{KH}$. Hasyim Asy'ari boarding generate all the power required by humans. ${ }^{12}$

$\mathrm{KH}$. Hasyim Asy'ari is one figure who is eager to reform and have great attention in the world of Islamic education. He was a prominent figure and founder of the Islamic organization Nahdlatul Ulama (NU) in $1926 \mathrm{M}$. He is a scholar who maintains the local tradition, the tradition of the Indonesian Islamic community with many different variants that are still in line with the principles of Islam along the combination has a foundation and religious purposes. Local Islamic concept which is reflected in his thinking construction also made the difference of views between Islam in the Middle East is thick

\footnotetext{
${ }^{9}$ Abdurrahman Al-Nahlawy, Prinsip-prinsip Dasar Metode Pendidikan Islam, terj. H. M. Dahlan (Bandung: Dipenogoro, 1989), 118-9.

${ }^{10}$ I. Syafi'i, "Pondok Pesantren: Lembaga Pendidikan Pembentukan Karakter," AlTadzkiya': Jurnal Pendidikan Islam, vol. 8, no. 1 2017, 65.

${ }^{11}$ H. A. R. Makmun, "Pembentukan Karakter Berbasis Pendidikan Pesantren: Studi di Pondok Pesantren Tradisional dan Modern di Kabupaten Ponorogo," Cendekia, vol. 12, no. 2, 2017, 1-2.

${ }^{12}$ A. Putra, "Pemikiran KH. Hasyim Asy'ari dan Konstribusinya terhadap Kajian Hadis di Indonesia," Wawasan: Jurnal Ilmiah Agama dan Sosial Budaya, vol. 1, no. 1, 2016. 54
} 
EVALUASI, 4 (1), Maret 2020, ISSN 2580-3387 (print) |

ISSN 2615-2886 (online)

Homepage : http://e-journal.staima-alhikam.ac.id/index.php/evaluasi

DOI : : http://doi.org/10.32478/evaluasi.v4i1.359

Article type : Review Article

with Arabismenya with a view of Islam in the $\operatorname{archipelago,~}^{13}$ so the complexion thoughts on education still seems a traditionalist. Culture Collection is thick with politeness, both in speech and deed, are clear in thinking.

There fore, this study is important to research Islamic educational thought by $\mathrm{KH}$. Hasyim Asy'ari that education problems are not finished like patching a hole then appears a new hole can be completed. His thoughts not only raised the question of classical education, but is also relevant to the character of modern education both system and institutional, not just a matter of character education, but all aspects alluded ranging from students, teachers, institutions, neighborhood to the realm of the curriculum. Thought he was very inappropriate studied and analyzed, for the development of national education can not be separated from the ideas and thoughts milestones, classical scholars.

\section{B. Methods}

This study used a qualitative approach, as a research procedure that produces descriptive data in the form of words written or spoken of people and observed behavior. ${ }^{14}$ Researcher examines $\mathrm{KH}$. Hasyim Asy'ari and Moderation Islamic Education: Study of Thinking KH. Hasyim Asy'ari on Education Boarding School and Its Relevance to Modern Education in Indonesia.

The type of research used literature research or the researcher is often called the library research that the study carried out to solve a problem that relies on a critical and in-depth study of the materials relevant literature. A literature review of this kind usually carried out by collecting data and information from various sources of information are then presented with new ways and new purposes. In this case, the library materials needed as a source of ideas to explore new thought or ideas, as the base material to

\footnotetext{
${ }^{13}$ Robi Sugara, "Reinterpretasi Konsep Bid'ah dan Fleksibilitas Hukum Islam Menurut Hasyim Asyari," Asy-Syari'ah, vol. 19, no. 1 (Juni, 2017). 37-48, https://doi.org/10.15575/as.v19i1.4029

14 Lexy J. Meleong, Metodelogi Penelitian Kualitalif, (Bandung: PT. Remaja Rosdakarya, 2013), 4

120
} 
EVALUASI, 4 (1), Maret 2020, ISSN 2580-3387 (print) |

ISSN 2615-2886 (online)

Homepage : http://e-journal.staima-alhikam.ac.id/index.php/evaluasi

DOI : : http://doi.org/10.32478/evaluasi.v4i1.359

Article type : Review Article

make deductions from the knowledge that already exists, so that the new theoretical framework can be developed or as basic troubleshooting. ${ }^{15}$

Data are facts, information or information that is used as a source or material discovered conclusions and make decisions. ${ }^{16}$ Based on the problems that have been formulated by the authors, the data of this study is thought KH. Hasyim Asy'ari on codes of conduct of teachers, both sourced from books, journals, scientific articles, and news papers.

\section{RESULTS}

\section{Biography KH.Hasyim Asy'ari}

KH.Hasyim Asy'ari full name was Muhammad Hasyim Asy'ari bin Abdurrahman bin Abdul Wahid, also known by the nickname Jaka Tingkir (Sultan Hadi Wijaya) Bin Abdul Aziz bin Abdullah bin Abdul Fatah, son of Maulana Ishak bin Ainul sure popularly known as Sunan Giri , Kyai Hasyim Asy'ari born of a couple of Kyai Ash'ari and Halimah on Tuesday kliwon February 14, 1871, M or coincide with the year 1287 H. 12 Dzulqa'dah his birthplace was around 2 kilometers north of the town of Jombang, wherein Pesantren Gedang, Papaw its elf was one hamlet arrives into the area administrative Tambakrejo Village District of Jombang. ${ }^{17}$

At the age of five, Hashim moved from the village to the Gedang Hard to follow his father and mother who are building new schools. He spent his childhood until the age of 15 years in the village. He then left the village Hard to learn too many renowned boarding schools in the country, even to Mecca. At the age of 21 years, precisely in $1892 \mathrm{M} . / 1308 \mathrm{H}$., she was married to Nafisa, the daughter of Jacob Kiai Siwalan Panji, Sidoarjo. After that, he was with his wife and her parents went to Mecca for pilgrimage. He and his wife then settled in Mecca to study. Seven months later, Nafisa died after giving birth to a son named Abdullah. 40 days later, his son, Abdullah, died

15 Fakultas Tarbiyah dan Ilmu Keguruan IAIN Ponorogo, Buku Pedoman Skripsi Revisi 2018 (Ponorogo: IAIN Ponorogo), 53.

${ }^{16}$ Mahmud, Metodelogi Penelitian Pendidikan, (Bandung: CV. Pustaka Setia, 2011), 146.

${ }^{17}$ Ahcmad Muhibbin Zuhri, Pemikiran KH. M. Hasyim Asy'ari Tentang Ahl AlSunnah Wa alJama'ah (Surabaya: Khalista, 2010), 67-68 
EVALUASI, 4 (1), Maret 2020, ISSN 2580-3387 (print) |

ISSN 2615-2886 (online)

Homepage : http://e-journal.staima-alhikam.ac.id/index.php/evaluasi

DOI : : http://doi.org/10.32478/evaluasi.v4i1.359

Article type : Review Article

after his mother. ${ }^{18}$ The death of two people she loves it makes Hashim hit. In the end, she decided not to linger in the holy land, so he went back to Indonesia a year later.

After a long-widowed, remarried with Khadijah Hashim, the daughter of the village Kiai Romli Karangkates, Kediri. This marriage took place after his return from Mecca in $1899 \mathrm{M}$ or $1315 \mathrm{H}$. His marriage to his second wife also did not last long, because Khadijah died two years later, in 1901, KH Hasyim Asy'ari later remarried to Nafiqah, daughter of Kyai llyas which is a boarding school caretakers Sewulan, Madiun. He was awarded ten children from his marriage to Nafiqah, namely: Hannah, Khoiriyah, Aisha, Azzah Abdul Hakim (Abdul Kholik), Abdul Karim, Ubaidullah, Mashuroh, and Muhammad Yusuf. ${ }^{19}$ Marriage Hashim with Nafiqah also stop halfway, because Nafiqah died in 1920 M, After the death of Nafiqah, he married again with Masrurah, daughter of Kiai Hasan who is the caregiver Pesantren Kapurejo, Capping, Kediri. He was awarded four children from his fourth marriage, namely: Abdul Qadir, Fatima, Khadija, and Muhammad Yaqub. His marriage with a wedding last Nafiqah and $\mathrm{KH}$. Hasyim until his death. ${ }^{20}$

In terms of pedigree, Hashim is a figure that can not be separated from boarding school life. He was born and grew up in boarding school tutelage of his father, Ash'ari. Kiai Usman, his grandfather, a famous scholar who pioneered and establish a pesantren Gedang. Kiai Sihah, her greatgrandfather, the founder of the Pesantren Tambak Beras in Jombang. Thus, it is reasonable Hashim became a scholar whose whole life can not be separated from boarding. Tebuireng pesantren in Jombang, the largest and most influential cottage in Jombang and East Java, a boarding school founded byKH. Hasyim. This pesantren still exists with thousands of students from various parts of the country today. ${ }^{21}$

18 Abdul Hadi, KH. Hasyim Asy'ari: Sehimpun Cerita, Cinta, dan Karya Maha Guru Ulama Nusantara, (Yogyakarta: DIVA Press, 2018), 17-18.

${ }^{19}$ Ishâm al-Dîn Hâdziq, "Al-Ta 'rîf bi al-Mu'allif," dalam Muhammad Hâsyim Asy'arî, Âdâb al- 'Alim wa alMuta 'allim (Jombang: Maktabah al-Turâts al-Islâmî, 1415 H.), 3.

20 Ishomuddin Hadziq, KH. Hasyim Asy'ari: Figur Ulama dan Pejuang Sejati (Jombang: Pustaka Warisan Islam, 1999),. 17

21 Supriyadi, Ulama Pendiri, Penggerak, dan Intelektual NU dari Jombang, (Jombang: Pustaka Tebuireng, t.th), 9-10

122 
EVALUASI, 4 (1), Maret 2020, ISSN 2580-3387 (print) |

ISSN 2615-2886 (online)

Homepage : http://e-journal.staima-alhikam.ac.id/index.php/evaluasi

DOI : : http://doi.org/10.32478/evaluasi.v4i1.359

Article type : Review Article

KH. Hasyim Asy'ari died in July 1943 in Jombang as high blood pressure or stroke after receive news about the current condition of Indonesia; on July 2, 1947, the envoy Tomo and Sudirman come to him to break the news of the Dutch military aggression Dutch bum I. Allied forces under General SH. Poor has defeated the Republican army occupying the Singosari. Even the Dutch forces have also targeted civilians, so many of them are victims. $^{22}$

As an intellectual, $\mathrm{KH}$. Hasyim Asy'ari has donated many valuable things for the development of civilization. Among his contributions is several religious and social literature. Hashim famous written work is as follows: First, al-Adab wa al-Muta'allim' alim, which describes the various matters relating to the ethics of educators and learners. Second, Ziyâdât al-Ta'lîất, which is a response to the opinion of Ibn Yasin Pasuruan different opinions about NU. Third, Al-Tanbîhât al-Wâjibât li bi man Yashna'al-Mawlid alMunkarât, which describes the people who celebrate the birthday of the prophet with injustice. Fourth, Al-Nur al-Mubin fi Mahabbah Sayyid alMursalin, which describes the love of the Prophet Muhammad. and matters related thereto, to be his followers, and revive the tradition. Fifth, Al-Durar al-fi al-Masa'il Muntasyirah al-Tis'a 'Asyarah, which explains the problems the congregation, trustees, and other important matters relating to both or followers of the Sufi. Sixth, Al-Risalah al-Jami'ah, which describes the state of the person who died, the signs of the apocalypse, as well as reviews of the Sunnah and heresy. ${ }^{23}$

\section{Objectives of Islamic Education and Character Education Perspective KH. Hasyim Asy'ari}

Education Renewal evolved since the early days of Islam until now. The hallmark of an idea influenced by social, political and religious constructs, making it a thought or literature associated with significant social

\footnotetext{
${ }^{22}$ Abdullah Hakam, "KH. Hasyim Asy’ari dan Urgensi Riyâdah dalam Tasawuf Akhlâqî," Teosofi: Jurnal Tasawuf dan Pemikiran Islam, vol. 4, no. 1 (Juni, 2014), 151, https://doi.org/10.15642/teosofi.2014.4.1.145-166.

${ }^{23}$ Syamsul A'dlom, "Kipah KH. Hasyim Asy'ari dalam Mengembangkan Pendidikan Agama Islam,” Jurnal Pusaka, Desember, 2014, 18.
} 
EVALUASI, 4 (1), Maret 2020, ISSN 2580-3387 (print) |

ISSN 2615-2886 (online)

Homepage : http://e-journal.staima-alhikam.ac.id/index.php/evaluasi

DOI : : http://doi.org/10.32478/evaluasi.v4i1.359

Article type : Review Article

circumstances. That is, the social environment and personal experiences will affect the pattern of thought. Moral or character education is the main spirit of Islamic literature and educational thought $\mathrm{KH}$. Hasyim Asy'ari. As attitudes and models of education stem from the statement that Islamic education is a means for achieving human beings, aware of who the creator, for what was created, do all the command and away from the ban and do good in the world with justice. ${ }^{24}$

Educational situation at the time. $\mathrm{KH}$. Hasyim Asy'ari changes and the rapid development of the old habits (traditional) to increasingly modern education, is influenced by the Dutch imperialist's education system which is getting stronger in Indonesia. ${ }^{25}$ Here, it will be explained in more depth on the thinking of $\mathrm{KH}$. Hasyim Asy'ari about the concept of Islamic education and character education consisting of the meaning and purpose of education, educators, students, and educational paradigms character:

\section{a. Education}

Character Education by KH. Hasyim Ashari falls into line Syafi'iyyah schools. KH. Hasyim Ashari often quoted figures Syafi'iyyah, this is caused by the fact that the educational experience, especially teaching in some schools of Java are dominated by books (yellow book) by Shafi. ${ }^{26}$ The other thing that the tendency of educational thought $\mathrm{KH}$. Hasyim Asy'ari explores the aesthetic values as breathe Sufism. Therefore, the view of education is always oriented to the foundation of Islam which is based on self-revelation and approaches through the Sufism. Thought $\mathrm{KH}$. Hasyim Asy'ari central means that education is the heart. ${ }^{27}$ Islamic education according to $\mathrm{KH}$. Hasyim Asy'ari is an attempt to humanize the whole man, so that man can taqwa (fear) to God, to observe all his commandments able to enforce justice

24 Nur Wahid Zaenal Abidin, "Konsep Kepribadian Guru Menurut KH. Hasyim Asy'ari (Telaah Kitab Adāb Al 'Ālim Wa Al Muta'Allim)” Tesis, UIN Walisongo, 2016, 41-43.

${ }^{25}$ Rohinah M. Noor, KH. Hasyim Asy'ari Memodernisasi NU \& Pendidikan Islam, (Jakarta: Grafindo Khazanah Ilmu, 2010), 25

${ }^{26}$ Suwendi, Konsep Pendidikan KH. Hasyim Asy'ari, (Ciputat: LekDis, 2005), 60.

27 KH. M. Hasyim Asy'ari, Etika Pendidikan Islam (Yogyakarta: Titian Wacana, 2007), 1. 
EVALUASI, 4 (1), Maret 2020, ISSN 2580-3387 (print) |

ISSN 2615-2886 (online)

Homepage : http://e-journal.staima-alhikam.ac.id/index.php/evaluasi

DOI : : http://doi.org/10.32478/evaluasi.v4i1.359

Article type : Review Article

on earth, work righteousness and interests, worthy of the title as being the noblest and highest rank of all kinds of Allah's creation. ${ }^{28}$

$\mathrm{KH}$. Hasyim Asy'ari believes human nature and the environment affect each other equally in shaping the personality of a person. It is considered that education contributes a lot to improve, enhance and educate the moral or human morals. Therefore, kijaji gives special attention to educating character through moral education. ${ }^{29}$

\section{b. Purpose of Education}

The purpose of education is the determination of the target to be achieved. In education the goal of becoming a very fundamental thing, because the role of the most important goals should be formulated in determining the direction of the educational process. The main purpose of real science by $\mathrm{KH}$. Hasyim Asy'ari is the science at a more practical level, namely to manifest in the form of action. The actions are based on science will give the benefit of its own that a provision in the hereafter. ${ }^{30}$

In discussing the primacy of science, $\mathrm{KH}$. Hasyim Asy'ari often quoted verse of the Qur'an that explains about the primacy of science so that his knowledge can be useful as a preparation for life in the hereafter. Because of the important science, law obliging man to seek to give a great reward. ${ }^{31}$ Thought KH. Hasyim Asy'ari is in line with the thinking of its predecessor, namely Ibn Jama'ah. He said busy for the science because God is more important than conducting worship sunna form of prayer, fasting, and prayer beads, because of the benefits of science solely to the owner and another human being, while the benefits of the Sunnah worship only to perpetrators alone. $^{32}$

There are three dimensions to be achieved in the education concept $\mathrm{KH}$. Hasyim Asy'ari, including the dimensions of science, practice, and

\footnotetext{
${ }^{28}$ Rohinah, Sistem Nilai dan Pendidikan, 18

${ }^{29}$ Ibid., 34.

30 Mukani, "Biografi KH Hasyim Asyari”, Lathiful Khuluq, Fajar Kebangunan Ulama (Yogyakarta: LKiS, 2000), 28

31 Syamsul Kurniawan, Jejak Pemikiran Tokoh Pendidikan Islam, (Jogyakarta: ArRuzz Media, 2013), 211.

${ }^{32}$ Badr al-Dîn ibn Jamâ'ah, Tadzkirah al-Sâmi 'wa al-Muta 'allim fî Âdâb al- 'Âlim wa al-Muta 'allim (Mesir: Dâr al-Âtsâr, 2005), 71.
} 
EVALUASI, 4 (1), Maret 2020, ISSN 2580-3387 (print) |

ISSN 2615-2886 (online)

Homepage : http://e-journal.staima-alhikam.ac.id/index.php/evaluasi

DOI : : http://doi.org/10.32478/evaluasi.v4i1.359

Article type : Review Article

religion. Scientific dimension, meaning the students are directed to always develop their knowledge, not only religion but the scientific general knowledge. Learners are required to be critical and sensitive to the environment. Dimensions learners practice can actualize their knowledge for the common good and responsible for the scholarly grace of God. As for the religious dimension, is the relationship between the Lord is not just a religious ritual but rather rely on everything to seek Rida Allah. ${ }^{33}$

In setting educational goals, $\mathrm{KH}$. Hasyim Asy'ari not be separated from the concept of Islam which he rested think that requires education to achieve two things. First, encouraging people to know God so consciously with full confidence to worship Him. Second, encourage people to understand the Sunnah of Allah in the universe who served as caliph fil ard. ${ }^{34}$ Thus, if observed that the purpose of education according to $\mathrm{KH}$. Hasyim Asy'ari is becoming a full human being that aims to draw closer to Allah SWT. and, a man after aiming at obtaining happiness of the world and the hereafter. Therefore learn to be intended to develop and preserve the values of Islam, not just eliminate ignorance.

Urgency education initiated by Hashim by the Constitution No. 20 of 2003 on National Education System, which reads: "The national education serves to develop the ability and character development and civilization of the nation's dignity in the context of the intellectual life of the nation, aims to develop the potential participants to become a man of faith and fear of God Almighty, the noble character, healthy, knowledgeable, skilled, creative, independent, and become citizens of a democratic and responsible. "this indicates that Hashim in line with the ideology and ideals of the nation of Indonesia to become the nation's dignity. ${ }^{35}$

\section{c. Educators / Teachers}

According to $\mathrm{KH}$. Hasyim Asy'ari educators are scholars. That the clergy as a general human symbol used typology best creature (khair al-bariyyah),

\footnotetext{
${ }^{33}$ Tamyiz Burhanudin, Akhlak Pesantren Solusi bagi Kerusakan Akhlak, (Yogyakarta: Ittaqa Press, 2001), 104

${ }^{34}$ Hasyim Asy'ari, Pendidikan Karakter Khas Pesantren terjemah kitab Adab'Alim wa al - Muta'allim terj. Rosidin. (Tanggerang: Tsmart Printing 2017), 88.

${ }^{35}$ UUD RI No. 20 Tahun 2003 tentang Sistem Pendidikan Nasional, Bab II, Pasal 3. 126
} 
EVALUASI, 4 (1), Maret 2020, ISSN 2580-3387 (print) |

ISSN 2615-2886 (online)

Homepage : http://e-journal.staima-alhikam.ac.id/index.php/evaluasi

DOI $\quad$ : http://doi.org/10.32478/evaluasi.v4i1.359

Article type : Review Article

so that rank lower level below the prophet. ${ }^{36} \mathrm{KH}$. Hasyim Asy'ari sees scholars as being possessed of closeness to God and continue to develop his mind as a tremendous potential and a commitment to seek knowledge to be redirected. Educators as people who have the scientific capacity should be prioritized rather than the learner, given the position of educator as a scholar or ahl al-ilm very close (taqwa) and rank higher than devout. In this case, $\mathrm{KH}$. Hasyim Asy'ari believes that people can demonstrate the integrity of divinity in social behavior is the best of God's creatures. Thus, all efforts in the achievement of social science and should reflect the values of the sublime and everything leaning to God.

$\mathrm{KH}$. Hasyim Asy'ari educators regard it as a very important part of education. For him, an educator is a person who is capable of transmitting his knowledge in addition to forming attitudes and ethics learners. ${ }^{37}$ Judging from the role of an educator to be very important in upholding moral values and ethics, KH. Hasyim Asy'ari was trying to emphasize that educators feel obliged to give directions and advice are meant for learners to familiarize their attitude to life, which is based akhlakhul karimah and guide learners toward the road that pleases God. ${ }^{38}$

According to $\mathrm{KH}$. Hasyim Ashari a teacher or scholar who teaches science should have a genuine intention, do not expect material alone. Also, teachers should be able to adjust between the words spoken in the presence of students with behavioral measures were done, so it must not only deliver alone. Criteria educators because of $\mathrm{KH}$. Hasyim Ashari is, keep morals in education. Not only the students demanded a fine character, what is the meaning of ethics is applied only to the students, if teachers are educated do not have a noble character.

Therefore, $\mathrm{KH}$. Hasyim also offers some ethics that must be owned by an educator, among others, always draw closer to God, not to use their knowledge to achieve keduaniawian alone, because it would be demeaning

\footnotetext{
${ }^{36}$ Hartono Margono, "KH. Hasyim Asy'ari Dan Nahdlatul Ulama: Perkembangan Awal Dan Kontemporer," Media Akademika, Vol. 26, no. 3, 2011, 337

37 Rijaluddin, Bunga Rampai Pendidikan Islam, (Jakarta: Pusat Kajian Islam UHAMKA, 2008).183

${ }^{38}$ Ibid.,
} 
EVALUASI, 4 (1), Maret 2020, ISSN 2580-3387 (print) |

ISSN 2615-2886 (online)

Homepage : http://e-journal.staima-alhikam.ac.id/index.php/evaluasi

DOI : : http://doi.org/10.32478/evaluasi.v4i1.359

Article type : Review Article

the grandeur of science, keep away from things that are not pleasing to Allah, fostering the spirit to increase knowledge, do not use science to brag way. ${ }^{39}$

\section{d. Learners}

$\mathrm{KH}$. Hasyim Asy'ari requires learners to obey and submit to the advice and orders educators. Even though it was one of the educators must be followed. Compliance learners in all things is a necessity. Therefore, any error in the educator better than the truth which is owned learners. Also, learners are not allowed to have an idea as opposed to educators. ${ }^{40}$ For learners to persevere and to learn in the process of optimizing the potential of sense as a very special gift from God. KH. Hasyim Asy'ari assumes science is a very great grace and look for it is worship, hence learners should cleanse themselves of deeds and reprehensible nature, pure science also brought closer by the pure in heart so meaningful.

Intentions for the prosecution of science should be based on the motivation solely for the sake of God, no earthly purpose or for private purposes, the practice of science, turned Shari'ah, illuminating the hearts, decorate conscience, intellectual thinking power expand and maintain the sanctity of the soul to attain the blessings God, Learners can take advantage of the best time to learn effectively. This time is used to sharpen knowledge. The use of time more clearly itemized by $\mathrm{KH}$. Hasyim Asy'ari among others the dawn of time to memorize the morning to review and discussion, the middle of the afternoon to write, and the evening for discussion and review. ${ }^{41}$

A student must have at least 10 kinds of ethics, namely: (a) Cleaning the liver of a variety of disorders of faith and worldliness; (b) Establish a noble intention, which seeks knowledge solely to earn Allah's pleasure. and determined to put it into practice after the knowledge acquired; (c) Not postpone delay time learning; (d) Patient and kanaah against all kinds of gifts and trials; (e) Timing; (f) Simplify food and beverage; (g) Be careful or warak; (h) Avoid foods and drinks that cause laziness that ultimately lead to

\footnotetext{
${ }^{39}$ Sururin, "Etika Pendidik dan Peserta didik menurut KH. Hasyim Asy'ari”, Tahdzib Jurnal Pendidikan Agama Islam Vol. III, No. 1, Januari 2009, 50

${ }^{40}$ Suwendi, Konsep Pendidikan KH. Hasyim Asy'ari, (Ciputat: LekDis, 2005).79

${ }^{41}$ Ibid,. 90

128
} 
EVALUASI, 4 (1), Maret 2020, ISSN 2580-3387 (print) |

ISSN 2615-2886 (online)

Homepage : http://e-journal.staima-alhikam.ac.id/index.php/evaluasi

DOI $\quad$ : http://doi.org/10.32478/evaluasi.v4i1.359

Article type : Review Article

ignorance; (i) Menyedikitkan bedtime while not harmful to health; and (j) Leaving things are less worthwhile. ${ }^{42}$ In this case, the student is not justified when studying only emphasize the things that are spiritual or worldly, since both are equally important.

\section{e. Character Building}

$\mathrm{KH}$. Hasyim Asy'ari believes in rectifying and educate moral character through moral education is a necessity. Even further described educational operations is essentially the interplay between the nature of the environment. Thus, the role of education in addition to work in developing the creativity and productivity, it also plays a major role in efforts to develop the values, both human values and the values of the divine. ${ }^{43}$

In the learning process, to achieve the desired objectives, by applying behaviors sublime. All conditions occur, the students always respond with kindness and morality al-karimah. Habituation is a must separate for learners to achieve learning goals. So, eventually learning has meaning and has a precious value that can take students to a higher degree. ${ }^{44}$

Education affects the character of human nature with its surroundings. Being in the middle of the home environment, the school and the community will establish the integrity of the personality of the child, and children themselves should be able to filter the values of the characters that will be used for life. In this case, learners and educators should straighten intention and attention to ethics (adab) which reflects the noble character and everything leaning to God. Thus, in the process of finding and disseminating knowledge seen from the main objective is expecting a blessing from Allah. So the importance of efforts to encourage the formation of positive character in human behavior is to live the noble values that are considered good and sticking to monotheism.

${ }^{42}$ Bad al-Dîn bn Jamâ'ah, Tadzkirah al-Sâmi 'wa al-Muta 'allim fî Âdâb al- 'Âlim wa alMuta'allim, (Mesir: Dâr al-Âtsâr. 2005). 203.

43 Rijaluddin, Bunga Rampai Pendidikan Islam, (Jakarta: Pusat Kajian Islam UHAMKA, 2008), 27

${ }^{44}$ Rohinah M. Noor, KH. Hasyim Asy'ari Memodernisasi NU \& Pendidikan Islam, (Jakarta: Grafindo Khazanah Ilmu, 2010), 2 
EVALUASI, 4 (1), Maret 2020, ISSN 2580-3387 (print) |

ISSN 2615-2886 (online)

Homepage : http://e-journal.staima-alhikam.ac.id/index.php/evaluasi

DOI : : http://doi.org/10.32478/evaluasi.v4i1.359

Article type : Review Article

Before the government announced a character education, long before that $\mathrm{KH}$. Hasyim Asy'ari was first applying the character values in educational activities in schools. Pesantren Tebuireng formative stages Ireng which is independent is one of the many values that developed pesantren. Then, when the struggle repels invaders role $\mathrm{KH}$. Hasyim Asy'ari as fighters scholars contributed to instilling patriotism to the students to uphold the independence of the nation of jihad in Indonesia. Pesantren in this case as an educational institution is deemed successfully formed the positive character of the students, as it employs a holistic education, in the form tarbiyah (learning) which includes study groups (teaching) and ta'dib (formation of character or discipline). ${ }^{45}$

\section{DISCUSSION}

\section{a. Relevance Between Thinking KH. Hasyim Asy’ari with Modern Education Condition}

In this section, we will discuss the relevance of thinking $\mathrm{KH}$. Hasyim Asy'ari with the conditions of today's modern education. The discussion will begin with the study of thought $\mathrm{KH}$. Hasyim Asy'ari related to boarding metamorphosis. Early departure educational thinking KH. Hasyim Asy'ari. KH. Hasyim Asy'ari starting from Pesantren Nggedang grandfather, KH. Uthman. From this variety of ideas and policies applied, though, of these boarding schools he studied education management. Only in the 26th Rabu'ul Early in $1317 \mathrm{AH}$ or 1899 AD Tebuireng she established boarding school not far from the Dutch-owned sugar factories.

On his journey, many families refuse Tebuireng pesantren development caused the type of people in the village behaves badly. But then, $\mathrm{KH}$. Hasyim Asy'ari replied Spreading Islam means improving the quality of human life. If humans have got a good life, what else should be improved of them? After all, running a jihad means to face adversity and sacrifice, or as the Apostle us in the struggle. ${ }^{46}$ In developing the Pesantren Tebuireng, $\mathrm{KH}$. Hasyim Asy'ari does not do it alone. He was helped by competent courtiers

${ }^{45}$ Lanny Octavia, Ibi Syatibi, dkk, Pendidikan Karakter Berbasis Tradisi Pesantren, (Jakarta: Yayasan Rumah Kita Bersama, 2014), 10

46 Arifin, Kepemimpinan Kiyai: Kasus Pesantren Tebuireng, (Jakarta: Kali Mandala Press, 1992), 47

130 
EVALUASI, 4 (1), Maret 2020, ISSN 2580-3387 (print) |

ISSN 2615-2886 (online)

Homepage : http://e-journal.staima-alhikam.ac.id/index.php/evaluasi

DOI $\quad$ : http://doi.org/10.32478/evaluasi.v4i1.359

Article type : Review Article

like Kyai Awi, KH. Ma'sun, KH. Baidlawi, KH. Ilyas and Kyai Wahid Hasyim. Between the years 1899-1916 Pesantren Tebuireng follow sorogan and bandongan teaching system. ${ }^{47}$

Sorogan system is learning undertaken by students I read the book/textbook in front of the teacher, if there is an error then immediately corrected by the teacher and the meaning distorted when it is explained by the teacher. while it is a system bendongan is a teacher/kiai read the book somewhere and then the students give meaning to the book. ${ }^{48}$ Both systems are jiblakan from other schools that trend applied there, then, two methods are the primary method in transformation activities of religious sciences to students. ${ }^{49}$

In the period 1916-1919, the madrasa curriculum is not just studying Islamic sciences alone. From 1919 to 1926 began to add lessons Indonesian (Malay), Mathematics, Earth Sciences, Dutch and History. In 1934, while studying at madrasa extended to six years because of the increasing curriculum initiated by schools. Curriculum change is not out of the current environment, in which the Netherlands asked to remove NU pesantren in the dictionary of the archipelago, which is then burned boarding Tebuireng Netherlands. But the struggle blessing the students, the Netherlands was repelled. Since then, KH. Hasyim Asy'ari understands very well that the general lesson to be learned by students mainly to stem the secularists who began arriving. It is not wrong, when $\mathrm{KH}$. Hasyim Asy'ari add a few lessons. ${ }^{50}$

This curriculum change, rather the demand caused by anyone, because of the existence of Islamic education when it is more prevalentproliferation of curriculum reform, with no leads to secularistic. The curriculum changes already smelled gelagatnya when $\mathrm{KH}$. Hasyim Asy'ari incorporates young names like $\mathrm{KH}$. Ma'shum educational background in Mekkah and $\mathrm{KH}$. Ilyas his background. $\mathrm{KH}$. Ilyas not only a teacher but also a

${ }^{47}$ A. Mujib Dkk, Intelektualisme Pesantren: Potret Tokoh dan Cakrawala Pemikiran di Era Perkembangan Pesantren, (Jakarta: Diva Pustaka, 2003), 324.

${ }^{48}$ Muh. Shofi al-Mubarok, "Dakwah dan Jihad dalam Islam: Studi atas Pemikiran KH. Hasyim Asy'ari," Profetika: Jurnal Studi Islam, vol. 16, no. 2, 2015, 139.

${ }^{49}$ Z. Dhofier, Studi Pandangan Hidup Kyai dan Visinya mengenai Masa Depan Indonesia, (Jakarta: LP3ES, 2011), 104.

50 A. Azra, Esei-esei Intelektual Muslim dan Pendidikan Islam, (Jakarta: Logos Wacana Ilmu, 1999), 104. 
EVALUASI, 4 (1), Maret 2020, ISSN 2580-3387 (print) |

ISSN 2615-2886 (online)

Homepage : http://e-journal.staima-alhikam.ac.id/index.php/evaluasi

DOI : : http://doi.org/10.32478/evaluasi.v4i1.359

Article type : Review Article

boarding school administration leadership. This leap is a breakthrough as well as a critical evaluation of the schools education during which only wrestle on the element of religious sciences alone, but if so continued education schools will be left far behind other educational institutions. ${ }^{51}$ Then, $\mathrm{KH}$. Hasyim Asy'ari realized that the general sciences should immediately be imparted to his students, in addition to religious knowledge is not removed, complementing the religious sciences which already exist because Islam is not familiar with the concept of separation of science as such.

Between the years 1932-1933 KH. Propose to KH Wahid Hasyim. KH. Hasyim Asy'ari a radical change in the system of boarding school teaching. The proposal was among others that bandongan system was replaced with a systematic tutorial system to develop the initiative and personality of the students. ${ }^{52}$ However $\mathrm{KH}$. Hasyim Asy'ari did not approve the proposal $\mathrm{KH}$. Wahid Hasyim. According to him, the radical change would create chaos among pesantren leaders. Then $\mathrm{KH}$. Wahid Hasyim builds libraries. The students are encouraged to read magazines and newspapers as much as possible. Thus the students obtain sufficient information about the issues of social, economic, and political, both domestic and abroad. Another important development in the hands of Pesantren Tebuireng $\mathrm{KH}$. Hasyim Asy'ari to start the introduction of courses in speech, Dutch, English, and typing.

Curriculum changes made by $\mathrm{KH}$. Hasyim Asy'ari used method sijtihadi al-ljtimaiyah. This is a method of policymaking (changes in the curriculum) based on the community needs to look at the social conditions. Historically, the Netherlands has also established Islamic institutions led by the reformists. ${ }^{53}$ They consider boarding school curriculum is no longer relevant with the times. In the end, $\mathrm{KH}$. Hasyim Asy'ari thinks that schools should be able to face the challenges of a very great age that comes from himself and the outside. Maintaining a curriculum inherited from predecessor by not replacing anything, be detrimental in successive

51 S. Maarif, "Inklusifitas Pesantren Tebuireng: Menatap Globalisasi dengan Wajah Tradisionalisme," Jurnal Pembangunan Pendidikan, vol. 3, no. 1, 2015, 85

52 Aguk Irawan, Akar Sejarah Etika Pesantren di Nusantara: Dari Era Sriwijaya Sampai Pesantren Tebu Ireng dan Ploso, (Tangerang: Pustaka IIMAN, 2018), 207.

53 M. Saridjo, Sejarah Pondok Pesantren di Indonesia. (Jakarta: Dharma Bhakti, 1979), 56.

132 
EVALUASI, 4 (1), Maret 2020, ISSN 2580-3387 (print) |

ISSN 2615-2886 (online)

Homepage : http://e-journal.staima-alhikam.ac.id/index.php/evaluasi

DOI $\quad$ : http://doi.org/10.32478/evaluasi.v4i1.359

Article type : Review Article

thereafter. Of note, manliness mainstream schools as religious education and character remain embedded appropriately.

At the end of the 19th century when it was known in Indonesia as the two systems of education for the indigenous population. First, the western education system introduced by the Dutch colonial government to prepare students to occupy positions of public administration. Second, the system of education provided to the students at the school Muslim teaching focus is the science of religion. ${ }^{54}$ Both systems are then integrated by $\mathrm{KH}$. Hasyim Asy'ari into a whole curriculum that is owned by the schools. KH. Hasyim Asy'ari educational thinking. Hasyim Ashari offers education to make it more modern pesantren (modern in the sense according to the need of the era). However, the nature of this modernity does not necessarily go with the flow without any filtering changes special. KH. Hasyim Asy'ari renowned as a scholar who can perform rigorous screening against religious traditions that it deems not have a base. Indirectly, the inclusion of a common curriculum also passes a rigorous ikhtiyar from him.

According to his thinking, schools must be open to changing times. As he did on Tebuireng boarding school, where the teaching material is given to the students not only religious sciences and Arabic, but there must also be changes to the system by teaching general science. Indirectly there are two sections taught by plagueantren. 1) Content that is diniyah with books/kitab kuning in Arabic as usul fiqh, hadith, tafsir, and others. 2) Content of a general nature that is material non-diniyah with books/literature both Indonesian and English-language Indonesian search, physics, history, mathematics, and others. ${ }^{55}$

\section{b. Relevance Ethics Teachers in Teaching According to KH. Hasyim Asy'ari with the Code of Conduct Teachers in Indonesia}

In building a national character, the teacher must be a professional. As a professional teacher should at least be able to master two major

\footnotetext{
${ }^{54}$ L. Khuluq, Fajar Kebangunan Ulama Biografi K.H. Hasyim Asy'ari. (Yogyakarta: LKiS, 2009), 21.

${ }_{55}$ M. V. Bruinessen, Kitab Kuning Pesantren dan Tarekat, (Bandung: Mizan, 1995,) 161.
} 
EVALUASI, 4 (1), Maret 2020, ISSN 2580-3387 (print) |

ISSN 2615-2886 (online)

Homepage : http://e-journal.staima-alhikam.ac.id/index.php/evaluasi

DOI : : http://doi.org/10.32478/evaluasi.v4i1.359

Article type : Review Article

characteristics in teaching, the teaching materials and participants didi. Mastery of these two elements that are needed to determine the methods and learning strategies. Karakterisrtik mastery of teaching materials covering the concepts, principles and theories front in teaching materials. The characteristics of learners to master teachers include values, interests, personality muliadan morals learners. Teachers should also be aware that learners indirectly also to observe the behavior of teachers in the learning process takes place. Applied learning methods teachers must also comply with the conditions of learners. Teachers also have to be a role to be a figure that gives an introduction to the science of knowledge to learners. Teachers also have to be a designer of educators to deliver learners to master science. ${ }^{56}$

Learning to those who do not understand. A teacher must be sincere in giving understanding and teaching to learners. Therefore, teachers should provide teaching with explanations and understandable language, create instances, raises the problem (case study) and so on. The learning material is repeated, if necessary, to give power to an understanding of learners. In this case, thinking $\mathrm{KH}$. Hasyim Asy'ari relevant to the code of ethics of teachers to learners on points two and three that a teacher must happy learning services based on the individual characteristics and develop an atmosphere of active learning, creativity, and a lot of fun. In his book $\mathrm{KH}$. Hasyim Asy'ari that a teacher in teaching should pay attention to each of the abilities of his students, teaching with not too long and create ease in the classroom. Therefore, a teacher should choose subjects by ability learners. The work that so that learners are not subjects that are beyond its ability, a teacher must teach with passion and a conversation with the teaching expertise.

In addition to teaching a teacher must have a sincere intention and sincere in conveying knowledge to the learners. With a heart iklas then a teacher would be comfortable carrying out their duties, so learners will also feel comfortable when taught by teachers who a lot of fun. If a teacher has no element of compulsion in teaching and it will make it less thought about the best way to search for information, knowledge, and the search for material-let lessons to learners in an appropriate manner.

\footnotetext{
${ }^{56}$ Rusdiana dan Yeti Heryati, Pendidikan Profesi Keguruan Menjadi Guru Inspiratif dan Inovatif (Bandung: CV Pustaka Setia, 2015), 46.
}

134 
EVALUASI, 4 (1), Maret 2020, ISSN 2580-3387 (print) |

ISSN 2615-2886 (online)

Homepage : http://e-journal.staima-alhikam.ac.id/index.php/evaluasi

DOI

: http://doi.org/10.32478/evaluasi.v4i1.359

Article type : Review Article

\section{c. Relevance Ethics Teachers Towards Students According to KH. Hasyim Asy'ari with the Code of Ethics Teachers in Indonesia}

In the learning process, teachers are required to establish interaction and communication with learners. Interaction and communication are implemented should be educative so that the learning process is effective. When interacting and educative communication, teachers must maintain professional relationships with students, not exploit for personal gain or group and do not violate norms, contained in the code of conduct of teachers to students. ${ }^{57}$ It is also relevant to thought $\mathrm{KH}$. Hasyim Asy'ari about ethics of teachers to students, that a teacher must be democratic, namely by giving the same behavior to students, without being discriminatory unless there is a specific reason. Furthermore, as an exalted in a learning process, teachers also have the ethics to their students. Among these ethics is compassion in the association, the attitude of gentleness in the mix. This means that teachers give a good example in the association between fellow teachers before the students, thus making it as education and learning for the benefit of ukhuwah Islamiyah and daily interaction they, as well as advise and admonish well when there are learners who are naughty and stubborn,

From the above explanation that the teacher as a guide, the definition of a supervisor as proposed by Ki Hajar Dewantara in the system among its "ing garso sung tulodho, ing madyo mangun karso, tutwuri handayani",, Which means that education should be able to give an example, should be able to exert their influence, and should be able to control the students. In a word, tut wuri let learners lack the intent to obey his talent, while teachers only pay attention. While the word Handayani means it teacher affects learners, in the sense of guiding or teaching. Thus, the guiding means being decisive towards the establishment of the Indonesian people fully spirited Pancasila, and not dictate learners, especially force it at the discretion of the teacher. ${ }^{58}$

57 Azyumardi Azra, "Pembaruan Pendidikan Islam: Sebuah Pengantar," dalam Marwan Saridjo, Bunga Rampai Pendidikan Islam. (Jakarta: Departemen Agama RI. 1997/1998), 50

58 M. Hosnan, Etika Profesi Pendidik Pembinaan dan Penetapaan Kinerja Guru, Kepala Sekolah, Serta Pengawas Sekolah, (Bogor: Gralia Indonesia, 2016), 108. 
EVALUASI, 4 (1), Maret 2020, ISSN 2580-3387 (print) |

ISSN 2615-2886 (online)

Homepage : http://e-journal.staima-alhikam.ac.id/index.php/evaluasi

DOI : : http://doi.org/10.32478/evaluasi.v4i1.359

Article type : Review Article

Furthermore, the duty of a teacher is not only with students but also parents of students and the community. The duties of a teacher can not be separated from social life, as a teacher who can not live without the help of others. Therefore, teachers need to establish interaction, communication, and collaboration with anyone to facilitate and succeed in their duties. Therefore, a teacher needs to establish a good relationship with the parents of learners and society. Interaction and communication in the form of cooperation that can facilitate the implementation of education. In the teachers interact and communicate with anyone without distinction, in this case, the teacher can interact and communicate with students, parents of students and friends match or friend profession.

The teacher needs to establish a relationship with the parents of students and fellow teachers in implementing the educational process, even with the community to promote and develop education.Teachers should liaise and interact with participant students, parents, community and friends profession that means a teacher must possess, social competence is the ability of teachers as part of the community to communicate and interact effectively with students, fellow educators, education, parents/guardians of students and the surrounding community. Social competence is the ability of teachers as part of the community, which at least has the following competencies: First, Communicate orally and functional information. Second, the use of information and communication technology functionally. Third, effective Hanging on learners, educators fellow education personnel and parents/guardians of students. Fourth, Associating politely with the surrounding community. ${ }^{59}$

$\mathrm{KH}$. Hasyim Asy'ari emphasis on teacher mastery of the components in the interaction just as a teacher should be well-spoken and good morals in society. It is relevant to establish a code of ethics teachers on effective communication and harmonious cooperation with the community. With todo interaction and communication with parents of learners, teachers can make the guidance and coaching to learners by communicating with students both inside and outside the school, knowing your child's personality and

59 Sururin, "Etika Pendidik dan Peserta didik menurut KH. Hasyim Asy’ari”, Tahdzib Jurnal Pendidikan Agama Islam Vol. III, No. 1, Januari 2009. 50

136 
EVALUASI, 4 (1), Maret 2020, ISSN 2580-3387 (print) |

ISSN 2615-2886 (online)

Homepage : http://e-journal.staima-alhikam.ac.id/index.php/evaluasi

DOI $\quad$ : http://doi.org/10.32478/evaluasi.v4i1.359

Article type : Review Article

family background of each, communication teachers only held solely for the benefit of learners. ${ }^{60}$

Social competence in these learning activities related closely with the teacher's ability to communicate with people around the school and community where teachers live so the role and how teachers communicate in society is expected to have its distinct characteristics with someone other than a teacher. The mission of the carried teacher is a humanitarian mission. Teaching and educating is humanizing task. Teachers must have a social competence for teachers is the speaker of the times. Sharper written by Ir. Sukarno in writing "Teacher In Future Development", he mentioned the importance of in-service teacher development is to be a community. Therefore, the task of the teacher is human services. ${ }^{61}$

\section{CONCLUSION}

According to $\mathrm{KH}$. Hasyim Asy'ari ethics that must be held by teachers are being muraqabah to God, sakinah, as an advisor and mentor, implement Islamic law, use their spare time to pray and prepare papers, media science make not seek worldly goals, prioritize important material and pay attention to teaching with the characteristics of individual learners, love all the students and fix the intention to seek the pleasure of Allah.

Understanding of the various ethics teacher who has been taught by $\mathrm{KH}$. Hasyim Asy'ari in the Kitab adab alim wa al muta'allim, relevant to it can be concluded several things. First, the educational thought $\mathrm{KH}$. Hasyim Asy'ari directs him towards the degree of humanity that is tailored to the talents, abilities, and potentials. This process will lead to the realization of human rights and obligations as a created being, it became the forerunner of character education. Second, education schools not only teach about the science of religion (hadith, fiqh usul, figh and so on) but must also incorporate knowledge / general science into the curriculum as a form responsive to human needs in his day. Because in essence, a caliph is required to fully understand the community.

${ }^{60}$ Ibid.,

${ }^{61}$ Suwendi, Konsep Pendidikan KH. Hasyim Asy'ari, (Ciputat: LekDis, 2005). 79 
EVALUASI, 4 (1), Maret 2020, ISSN 2580-3387 (print) |

ISSN 2615-2886 (online)

Homepage : http://e-journal.staima-alhikam.ac.id/index.php/evaluasi

DOI : : http://doi.org/10.32478/evaluasi.v4i1.359

Article type : Review Article

Third,a teacher must be democratic, namely by giving the same behavior to students, without being discriminated unless there is a specific reason. This is relevant to the code of ethics of teachers in Indonesia that respects the dignity, the rights of learners in a fair and objective. Furthermore, KH. Hasyim Asy'ari emphasis on teacher mastery of the components in the interaction just as a teacher should be well-spoken and good morals in society. This is relevant to the code of ethics of teachers in Indonesia that a teacher must establish effective communication and harmonious cooperation with the community.

\section{References}

A. Azra, Esei-esei Intelektual Muslim dan Pendidikan Islam, Jakarta: Logos Wacana IImu, 1999.

A. Mujib Dkk, Intelektualisme Pesantren: Potret Tokoh dan Cakrawala Pemikiran di Era Perkembangan Pesantren, Jakarta: Diva Pustaka, 2003.

A'dlom, Syamsul, “Kipah KH. Hasyim Asy'ari dalam Mengembangkan Pendidikan Agama Islam," Jurnal Pusaka, Desember, 2014.

Abidin, Nur Wahid Zaenal, "Konsep Kepribadian Guru Menurut KH. Hasyim Asy'ari (Telaah Kitab Adāb Al 'Ālim Wa Al Muta'Allim)" Tesis, UIN Walisongo, 2016.

Al Mubarok. Muh Shofi and Sudarno Shobron, "Dakwah Dan Jihad Dalam Islam: Studi Atas Pemikiran KHM Hasyim Asy'ari," Profetika: Jurnal Studi Islam, Vol. 16, no. 2 (2017).

Al-Nahlawy, Abdurrahman, Prinsip-prinsip Dasar Metode Pendidikan Islam, terj. H. M. Dahlan, Bandung: Dipenogoro, 1989.

Arifin, Kepemimpinan Kiyai: Kasus Pesantren Tebuireng, Jakarta: Kali Mandala Press, 1992. 
EVALUASI, 4 (1), Maret 2020, ISSN 2580-3387 (print) |

ISSN 2615-2886 (online)

Homepage : http://e-journal.staima-alhikam.ac.id/index.php/evaluasi

DOI : $\quad$ http://doi.org/10.32478/evaluasi.v4i1.359

Article type : Review Article

As'ad, Mahrus, "Pembaruan Pendidikan Islam KH. Hasyim Asy'ari", Jurnal TSAQOFAH, Vol. 8 No. 1 April 2012,

Asy'ari, KH. M. Hasyim, Etika Pendidikan Islam, Yogyakarta: Titian Wacana, 2007.

Azra, Azyumardi, "Pembaruan Pendidikan Islam: Sebuah Pengantar," dalam Marwan Saridjo, Bunga Rampai Pendidikan Islam. Jakarta: Departemen Agama RI. 1997/1998.

Bad al-Dîn bn Jamâ'ah, Tadzkirah al-Sâmi'wa al-Muta'allim fî Âdâb al-'Âlim wa alMuta'allim, Mesir: Dâr al-Âtsâr. 2005.

Bruinessen, M. V, Kitab Kuning Pesantren dan Tarekat, Bandung: Mizan, 1995.

Fakultas Tarbiyah dan Ilmu Keguruan IAIN Ponorogo, Buku Pedoman Skripsi Revisi 2018, Ponorogo: IAIN Ponorogo, 2018.

Hadi, Abdul, KH. Hasyim Asy'ari: Sehimpun Cerita, Cinta, dan Karya Maha Guru Ulama Nusantara, Yogyakarta: DIVA Press, 2018.

Hâdziq, Ishâm al-Dîn, "Al-Ta'rîf bi al-Mu'allif," dalam Muhammad Hâsyim Asy'arî, Âdâb al-'Âlim wa alMuta'allim Jombang: Maktabah al-Turâts al-Islâmî, $1415 \mathrm{H}$.

Hadziq, Ishomuddin, KH. Hasyim Asy'ari: Figur Ulama dan Pejuang Sejati, Jombang: Pustaka Warisan Islam, 1999.

Hakam, Abdullah, “KH. Hasyim Asy'ari dan Urgensi Riyâdah dalam Tasawuf Akhlâqî," Teosofi: Jurnal Tasawuf dan Pemikiran Islam, vol. 4, no. 1 (Juni, 2014), https://doi.org/10.15642/teosofi.2014.4.1.145-166.

Hartono Margono, “KH. Hasyim Asy'ari Dan Nahdlatul Ulama: Perkembangan Awal Dan Kontemporer," Media Akademika, Vol. 26, no. 3, 2011. 
EVALUASI, 4 (1), Maret 2020, ISSN 2580-3387 (print) |

ISSN 2615-2886 (online)

Homepage : http://e-journal.staima-alhikam.ac.id/index.php/evaluasi

DOI : : http://doi.org/10.32478/evaluasi.v4i1.359

Article type : Review Article

Hasyim Asy'ari, Pendidikan Karakter Khas Pesantren terjemah kitab Adab'Alim wa al - Muta'allim terj. Rosidin. Tanggerang: Tsmart Printing 2017.

I. Syafi'i, "Pondok Pesantren: Lembaga Pendidikan Pembentukan Karakter," Al-Tadzkiya': Jurnal Pendidikan Islam, vol. 8, no. 12017.

Irawan, Aguk, Akar Sejarah Etika Pesantren di Nusantara: Dari Era Sriwijaya Sampai Pesantren Tebu Ireng dan Ploso, Tangerang: Pustaka IIMAN, 2018.

K. Hitty, Philip, History of the Arabs, London: Macmillan Press, 1974.

Khuluq, L., Fajar Kebangunan Ulama Biografi K.H. Hasyim Asy'ari, Yogyakarta: LKiS, 2009.

M. Hosnan, Etika Profesi Pendidik Pembinaan dan Penetapaan Kinerja Guru, Kepala Sekolah, Serta Pengawas Sekolah, Bogor: Gralia Indonesia, 2016.

Mahmud, Metodelogi Penelitian Pendidikan, Bandung: CV. Pustaka Setia, 2011.

Makmun, H. A. R., "Pembentukan Karakter Berbasis Pendidikan Pesantren: Studi di Pondok Pesantren Tradisional dan Modern di Kabupaten Ponorogo," Cendekia, vol. 12, no. 2, 2017.

Meleong, Lexy J, Metodelogi Penelitian Kualitalif, Bandung: PT. Remaja Rosdakarya, 2013.

Mukani, "Biografi KH Hasyim Asyari", Lathiful Khuluq, Fajar Kebangunan Ulama, Yogyakarta: LKiS, 2000.

Nata, Abuddin, Kapita Selekta Pendidikan Islam, Bandung: Penerbit Angkasa, 2003. 
EVALUASI, 4 (1), Maret 2020, ISSN 2580-3387 (print) |

ISSN 2615-2886 (online)

Homepage : http://e-journal.staima-alhikam.ac.id/index.php/evaluasi

DOI : $\quad$ http://doi.org/10.32478/evaluasi.v4i1.359

Article type : Review Article

Noor, Rohinah M., KH. Hasyim Asy'ari Memodernisasi NU \& Pendidikan Islam, Jakarta: Grafindo Khazanah Ilmu, 2010.

Octavia, Lanny, Ibi Syatibi, dkk, Pendidikan Karakter Berbasis Tradisi Pesantren, Jakarta: Yayasan Rumah Kita Bersama, 2014.

Putra, A, "Pemikiran KH. Hasyim Asy'ari dan Konstribusinya terhadap Kajian Hadis di Indonesia," Wawasan: Jurnal IImiah Agama dan Sosial Budaya, vol. 1, no. 1, 2016.

Rais, Amin, Tauhid Sosial: Formula Menggempur Kesenjangan, Bandung: Mizan, 1998.

Rijaluddin, Bunga Rampai Pendidikan Islam, Jakarta: Pusat Kajian Islam UHAMKA, 2008.

Rohinah, "Sistem Nilai dan Pendidikan (Studi atas Pemikiran Pendidikan KH. M. Hasyim Asy'ari)", Konsentrasi Pendidikan Agama Islam Sekolah Pascasarjana UIN Syarif Hidayatullah Jakarta, 2008.

Rusdiana dan Yeti Heryati, Pendidikan Profesi Keguruan Menjadi Guru Inspiratif dan Inovatif, Bandung: CV Pustaka Setia, 2015.

S. Maarif, "Inklusifitas Pesantren Tebuireng: Menatap Globalisasi dengan Wajah Tradisionalisme," Jurnal Pembangunan Pendidikan, vol. 3, no. $1,2015$.

Saerozi, Muh, Pembaruan Pendidikan Islam: Studi Historis Indonesia dan Malaysia1900-1942, Yogyakarta: Tiara Wacana, 2013.

Saridjo, M., Sejarah Pondok Pesantren di Indonesia, Jakarta: Dharma Bhakti, 1979.

Sugara, Robi, "Reinterpretasi Konsep Bid'ah dan Fleksibilitas Hukum Islam Menurut Hasyim Asyari," Asy-Syari'ah, vol. 19, no. 1 (Juni, 2017),https://doi.org/10.15575/as.v19i1.4029. 
EVALUASI, 4 (1), Maret 2020, ISSN 2580-3387 (print) |

ISSN 2615-2886 (online)

Homepage : http://e-journal.staima-alhikam.ac.id/index.php/evaluasi

DOI : : http://doi.org/10.32478/evaluasi.v4i1.359

Article type : Review Article

Supriyadi, Ulama Pendiri, Penggerak, dan Intelektual NU dari Jombang, Jombang: Pustaka Tebuireng, t.th.

Sururin, "Etika Pendidik dan Peserta didik menurut KH. Hasyim Asy'ari", Tahdzib Jurnal Pendidikan Agama Islam Vol. III, No. 1, Januari 2009.

Suwendi, Konsep Pendidikan KH. Hasyim Asy'ari, Ciputat: LekDis, 2005.

Syamsul Kurniawan, Jejak Pemikiran Tokoh Pendidikan Islam, (Jogyakarta: ArRuzz Media, 2013.

Tamyiz Burhanudin, Akhlak Pesantren Solusi bagi Kerusakan Akhlak, Yogyakarta: Ittaqa Press, 2001.

Tibawi, A.L, Islamic Education: Its Traditions and Modernization into the Arab National Systems, London: Luzac, 1972.

Umdirah, Abdurrahman, Metode al-Qur'an dalam Pendidikan, alih bahasa; Abdul Hadi Basulthanah, Surabaya: Mutia Ilmu, tt.

Usa, Muslih, Pendidikan Islam di Indonesia Antara Cita dan Fakta, Yogyakarta: Tiara Wacana, 1991.

UUD RI No. 20 Tahun 2003 tentang Sistem Pendidikan Nasional, Bab II, Pasal 3.

Yuliyanti, Rini, “Hubungan Guru Dan Murid Menurut KH. Hasyim Asy'ari Dan Implementasinya Dalam Tradisi Pembelajaran Di Pondok Pesantren Nurul Hikmah" Undergraduate, UIN Raden Intan Lampung, 2017. http://repository.radenintan.ac.id/1371/

Z. Dhofier, Studi Pandangan Hidup Kyai dan Visinya mengenai Masa Depan Indonesia, Jakarta: LP3ES, 2011.

Zuhri, Ahcmad Muhibbin, Pemikiran KH. M. Hasyim Asy'ari Tentang Ahl AlSunnah Wa alJama'ah, Surabaya: Khalista, 2010. 